\title{
Tarihi Kent Merkezlerinin Kırılganlığı ve Afet Yönetimi Üzerine Bir Değerlendirme: Ankara Saraçlar Sokağı Yangını Örneği
}

*

\author{
Ezgi Orhan \\ Çankaya Üniversitesi
}

\section{Öz}

Çalışma, 21 Şubat 2012'de Ankara'nun tarihi kent merkezi Ulus'ta Saraçlar Sokak'ta meydana gelen yangin örneği üzerinden tarihi merkezlerindeki iş alanlar için afet yönetim politikaları geliştirmeyi amaçlamaktadır. Ulus kent merkezinde yaşanan afet ve sonrasındaki deneyimlerden hareketle tarihi iş çeorelerinde kırılganliklarn yaratan etkenlerin neler olduğu ve bu alanlarda afet sakınım stratejileri geliştirilmesi gerekliliği üzerine yoğunlaşmaktadır. Çalışma, Saraçlar Sokak yangin olayı incelemesine göre literatürde yer alan kültürel varlıkların korunması, kentsel kırılganlık, işyeri sürekliliği ve tarihi kentsel alanlarda afet yönetimi konularındaki tartışmaları bütünleştirmektedir. Çalışmanın temel savı, tarihi kent merkezlerinin mekânsal ve sosyoekonomik niteliklerinin neden olduğu sorunların yanı sıra alanda yer alan iş faaliyetinden kaynaklanan sorunlarm da bu alanlarda kentsel risk üretimine katkı koyduğudur. Ulus Tarihi Kent Merkezi'nde mekansal örüntünün, sosyo-ekonomik yapının ve iş etkinliklerinin şekillenişini tarif etmek için alanın planlama tarihi incelenmiş ve bu başliklar altında kentsel kırllganlikların üretimine katkı koyan uygulamaların neler olduğu irdelenmiştir. Mekansal yapının yapılaşma düzeni, erişilebilirlik ve altyapı sunumundaki sorunlar nedeniyle kırılganlıkları üretmesi; sosyoekonomik yapıda kırılganları oluşturan etkenlerin tarihi kent merkezinin kullanıcılarının özellikleri ve ekonomik ve kurumsal birikimin alanı yenileştirme kapasitesinin sınırlı olması ile ilişkili olması; ve işyeri nitelikleri ve alanda nüfus yoğunluğu yaratmaları bakımından iş faaliyetinin alanda kırılganlıklara yol açması üzerinden bir değerlendirme yapılmıştır. Bu doğrultuda, tarihi alanların korunması ve ekonomik aktivitenin sürekliliği bakımından tarihi kent merkezlerine yönelik geliştirilecek afet yönetim politikaları ortaya konulmaktadır.

Anahtar Kelimeler: Tarihi kent merkezi, afet yönetimi, kırılganlık, kültürel varlıkların korunması, işyeri sürekliliği 


\title{
An Overview on Vulnerability and Disaster Management of Historical City Centers: The Case of Ankara Saraclar Street Fire
}

\author{
Ezgi Orhan \\ Çankaya University
}

\begin{abstract}
This study aims to develop a policy guideline for disaster management of business districts in historical centres with respect to the fire event realized in the Saraclar Street of Ulus historical city centre of Ankara on February 21, 2012. Departing from the disaster in Ulus city centre and following experience, the study focuses on the factors that affect urban vulnerability and the development of disaster mitigation strategies for historical business districts. The study combines the case of Saraclar Street fire and the literature on conservation of cultural properties, urban vulnerability, business continuity and disaster management in historical urban settings. The main argument of the study is that as well as the problems caused by the physical and spatial characteristics of historical city centres, the problems led by the business activities contribute to the urban risk production. Planning history of the area was investigated in order to explain the formation of spatial pattern, socio-economic structure, and business activity; and the factors that contribute to the production of urban vulnerability were analysed. This investigation argues that spatial structure produces vulnerability factors with respect to the problems related with building order, accessibility and infrastructure; the determinants of vulnerability of socioeconomic structure relate with the user characteristics of historical city centre and limited regeneration capacity of economic and political order; and business operations increase vulnerability of historical centres due to their business characteristics and user attraction nature. Accordingly, disaster management policies addressing to historical city centres are put forward with respect to the conservation of historical sites and continuity of economic activity.
\end{abstract}

Keywords: Historical city centers, disaster management, urban vulnerability, conservation of cultural properties, business continuity 


\section{Giriş}

Tarihi kentsel alanların karşılaştığı sorunlardan biri doğal, beşeri veya teknolojik kaynaklı afetlerdir. Tarihi kent merkezlerini de içeren kültürel mirasın korunması konusu İkinci Dünya Savaşı sonunda gündeme gelmiş; UNESCO tarafından başlatılan girişimlerle kültürel mirasın korunması ve rehabilitasyonu ilgili devletlerin benimsenmesi gereken ilkeler tanımlanmıştır. Dinçer (2012) çalışmasında kültürel mirasın korunmasında risklere hazırlık kavramının 1954 Lahey Sözleşmesi'nden günümüze değin uluslararası düzeyde kabul edilen anlaşmalarla geliştiğini göstermektedir. Özellikle 2000li yıllardan itibaren doğal afetler kültürel mirası etkileyen faktörlerden biri olarak kabul edilmiş ve UNESCO Dünya Miras Komitesi tarafından 2007 yılında kabul edilen Dünya Miras Varlıklarında Risk Azaltma Stratejisi'nde afet risklerinin azaltılmasına yönelik olarak uygulanacak politikalar belirlenmiştir (UNESCO, 2017). Bu çerçevedeki stratejiler arasında afet risklerinin tanımlanması ve risk faktörünü oluşturan nedenin azaltılması hedefler yer almıştır.

Kırılganlık pek çoğu insan kontrolü altında olan etkenlerin karmaşık etkileşimi sonucu oluşur ve doğal, beşeri ve teknolojik tehlikeler meydana geldiğinde yıkıcı ve geri dönülmez sonuçları olan afetlere dönüşebilir. Uluslararası Afet Azaltma Stratejisi (UNISDR) sekterliğini yürüten Birleşmiş Milletler Afet Riski Azaltma Ofisi doğal afetlere karşı önleme ve yanıt politikaları üretmek üzere uluslararası platformda çalışmaktadır. Platformun temel çıktılarından olan 2005-2015 Hyogo Eylem Çerçevesi'ne göre hayati sosyal donatı ve fiziki altyapının yanı sıra "kültürel değer taşıyan alan ve yapıların uygun tasarım, güçlendirme ve yeniden inşa yoluyla tehlikeye karşı dirençli kılmak için korunması" gereği vurgulanmıştır (UNISDR, 2005, s.11). Daha kapsamlı şekilde kültürel mirasın korunmasında yer veren 20152030 Sendai Afet Riski Azaltma Çerçevesi'ne göre "ilgili yer, afet ve kırılganlık bilgileri uyarınca afetlerin kültürel mirasa etkilerinin anlaşılması ve afet kayıplarının sistemli olarak kaydedilmesi, değerlendirilmesi ve paylaşılması" yerel ve ulusal düzeydeki eylem öncelikleri arasında yer almaktadır (UNISDR, 2015, s.15).

Uluslararası düzlemde kabul gördüğü gibi kültürel miras niteliği taşıyan tarihi kent merkezi ve iş alanlarının afet risklerine karşı duyarlılıklarını anlamak yere özgü ve olay özelinde değerlendirme gerektirmektedir. Bu çalışma Ankara'nın tarihi kent merkezi olan Ulus koruma yenileme alanı içerinde yer alan ve Samanpazarı Bölgesi'ndeki Saraçlar Sokak'ta 21 
Şubat 2012'de meydana gelen yangın olayı örneğini incelemektedir. Yangın, tekstil alanında faaliyet gösteren bir işyerinde gece 02.20 'de meydana gelmiş olup 5 saat süren söndürme çalışmaları süresince çevredeki işyerlerini de etkilemiştir. Yangınla birlikte 7 işyeri ağır maddi hasar görmüş ve birçok işyerinin stoklarının önemli bir bölümü söndürme çalışmaları sırasında kullanılamaz hale gelmiştir. Ankara Ticaret Odası'nın açılamalarına göre 100 kişinin işsiz kaldığ 1 ve yaklaşık 20 milyon liralık zararın oluştuğu belirtilmiştir (NTV haber sitesi, 2012). Ankara'nın toptan ve perakende tekstil alışverişinin önemli bir parçası olan Saraçlar Çarşısı'nda çıkan yangın, tarihi kent merkezlerinin ve bu alanda faaliyet gösteren işyerlerinin ürettikleri kırılganlıkların afetlere nasıl dönüştüğünü ve afet yönetiminin nasıl yapılması gerektiği sorununun ortaya atılmasını sağlamıştır.

Ulus kent merkezinde yaşanan afet ve sonrasındaki deneyimlerden hareketle tarihi iş çevrelerinin kırılganlıklarını meydana getiren etmenler üç boyutta tartışılmıştır; geleneksel olarak üretilmiş mekansal dokunun oluşturduğu riskler, alandaki sosyo-ekonomik yapının oluşturduğu riskler ve alandaki iş faaliyetinden kaynaklanan riskler. Alanın afet kırılganlıkları tarihsel gelişim süreci içinde ve planlama kararları bağlamında incelenmiştir. Örnek olayda etkilenen işyerleri ile derinlemesine görüşme yapılmış, tespitler iş faaliyetinden kaynaklanan kırılganlıkları açıklamada yorumlanmıştır. Elde edilen çlkarımlar doğrultusunda, tarihi kentsel merkezlerin korunması ve ekonomik aktivitenin sürekliliği bakımından geliştirilecek afet yönetim politikaları ortaya konulmaktadır.

\section{Alanın Ankara Planlama Tarihindeki Yeri}

Çalışma alanı, Ankara'nın tarihi kent merkezi Ulus içinde yer almaktadır. Kale yakınlarında konumlanan bu bölge kentin en eski yerleşimlerinden yeni bir başkentin inşasına ve günümüze kadar yaşanan tüm dönemleri barındıran bir yerleşimdir. Kent 15. yüzyılda Kale surlarının dişında yerleşmeyi sürdürmüş, bu dönemin temel üretim ve ticaret ürünü olan sof üzerine kurulu bir altyapı geliştirilmiştir. Özellikle Osmanlı Dönemi'nin idare anlayışıyla birlikte ekonomik örgütlenmeyi sağlayan ahi teşkilatı esnaf örgütlenmeleriyle mekânsal yapıyı biçimlendirmiştir. Samanpazarı Kale'nin dışında kalan ihtisaslaşan bir ticaret bölgesi olarak gelişmiştir. Ankara, Cumhuriyet'in ilanıyla başlayan modernleşme projesinin model kenti olarak kurgulanmış, bununla birlikte tüm yapılar ve mekanlarla yeni 
rejimin gücü, devletin saygınlığ 1 ve modern kamusallığı temsil etmesi amaçlanmıştır (Orhan, 2013).

Ankara'nın planlama süreci hem yeni rejimi simgelemesi hem de kentin büyümesinin yönlendirilmesi gerekçelerinin sonucu olarak gündeme gelmiştir. Kentin ilk gelişme planı girişimleri 1923 yılına uzanmaktadır, Lörcher Planı Cumhuriyet kurumlarının, bulvar ve meydanlarının mekansal temelini oluşturmuştur (Cengizkan, 2004; 2006; Günay, 2006). Lörcher'le kentin ilk planının hazırlanması için anlaşılmış ancak eski kentin dönüşümünü içeren önerileri konusundaki anlaşmazlıklar nedeniyle plan kısmen reddedilmiştir. Bademli (1985) oluşabilecek arsa spekülasyonları nedeniyle eski yerleşimde herhangi bir planın başarıyla uygulanmasının mümkün olmadığını ileri sürmüştür. Diğer taraftan, artan konut ihtiyacını karşılayabilmek için Plan'ın öngördüğü yeni gelişim alanı önerisi kabul görmüştür. Ancak, bu ilk planın kapsamının sınırlığı ve kuruluş aşamasını yönlendirecek nitelikte olmaması, Ankara için yeni bir plan hazırlanması ihtiyacını doğurmuştur. Kentin gelişmesini düzenlemek gerekçesiyle 1927 yılında Ankara'nın nazım planı için uluslararası bir yarışma düzenlenmiştir ve plan hükümlerini uygulayabilmek üzere 1928 yılında Dahiliye Vekaleti'ne bağlı olarak 1351 sayılı yasa ile Ankara İmar Müdürlügü kurulmuştur. Yarışmayı kazanan Prof. Hermann Jansen'in planı 1932'de yürürlüğe girmiş ve bu plan Kurtuluş Savaşı'ndan sonraki yirmi yıl boyunca yeni başkenti inşa etme sürecini yönlendirmiştir. Jansen'in planının seçilmesinin başlıca sebebi yeşil alan önerileri getirmesi ve sosyal bağlamı, araba çağının gereksinimlerini, sanayi ve işçi konutlarını dikkate alışıdır (Tankut, 1993).

Nüfus artışılla oluşacak kentsel gelişmeyi düzenlemek amacıyla yapılan planda Jansen, kentsel işlevleri coğrafi olarak farklılaştıran bir bölgeleme yaklaşımını benimsemiştir. Böylece, idare, konut, rekreasyon, sanayi, sağlık ve eğitim bölgeleri oluşturulmuştur. Ulus'ta idari, ticari ve kültürel faaliyetlerinin yoğunlaşmasının yanı sıra Jansen Planı'nda kentin güney uzantısında Yenişehir bölgesi tasarlanmış, bu alana eski kentte dağınık ve elverişsiz koşullarda bulunan bakanlık yapılarının yerleştirilmesi ve yeni konut alanlarının açılması planlanmıştır. Atatürk Bulvarı kentin eski ve yeni şehirlerini ve bu işlevleri birbirine bağlayan kuzey-güney yönelimli bir eksen olarak tasarlanmıştır. Ulus'taki Birinci Millet Meclisi'nden başlayıp Çankaya'daki Cumhurbaşkanlığı Köşkü'ne kadar uzanan Bulvar, şehrin bu iki kesimini birbirine bağlayarak, yapıların aldıkları konumla biçimlenerek kentin dinamosunu oluşturmuştur. Jansen'in Kale'yi çevreleyen gelişme önerisinde geleneksel dokunun korunmasına yönelik bir Protokol 
Sahası öngörülmüştür; buna göre "tarihi kıymetin pek fazla olmasından eski şehir kısmının işlenmesinde çok özenli olunmasının" altı çizilmiştir.

Planlı gelişme girişimlerinin yanı sıra sınırlı kamusal kaynaklarla mevcut dokuya müdahale etme kapasitesinin yetersiz kalması nedeniyle kentlerin imarıla eski kent - yeni kent ikilemi doğmuştur. Eski kent korunması gereken bir tarihi miras olarak görülürken, yeni kent sanayi gelişimi ve ilerlemenin uzantısı olarak tanımlanmaktadır (Keskinok, 2010, s.185). Lörcher Planı'yla temelleri atılan iki merkezli kent yapısı, Jansen'in demiryolu hattnı planında ana eksenlerden biri olarak belirlemesiyle daha da belirginleşmiştir. Günay'a (2006) göre bu iki planın uzantısı olarak Ulus'ta Kale'nin batısı, Hacıbayram çevresi ve Kale dışında eski dokunun tamamen yenilenmesi sonucunda oluşturulan caddeler boyunca yüksek ve sürekli bir yapılaşma ortaya çıkmış, iç kesimler ise çöküntü bölgesine dönüşmüştür (s.75). Kale çevresindeki yapıların yenilenmesi ve alanın iyileştirilmesine yönelik politikalar 1980 sonrası döneme bırakılacaktır.

1950lere gelindiğinde Ankara Jansen Planı'nın varsaydığı nüfus büyüklüğüne erişmiş, eski merkez çevresinde gecekondulaşma başlamıştır. Bu döneme değin, tarihi yerleşim içinde Jansen Planı dışında uygulamalar yapılmış, Talatpaşa Bulvarı, Ulucanlar, Denizciler ve Anafartalar Caddeleri açılmıştır (Şahin Kadakal ve Ubay Tönük, 2016). 1955'te kentin hızla artan nüfusunu yerleştirme ihtiyacını çözmek amacıyla 1957 yılında düzenlenen yarışmayı Nihat Yücel ve Raşit Uybadin kazanmıştır. Plan müellifleri kentin ana omurgası çevresinde düşük yoğunluklu ayrık nizamlı yeni yerleşim alanları açmıştır. Ancak, 1960ların sonunda artan nüfus, yeniden bütüncül bir planlama çalışmasıyla ele alınmamış, Yücel-Uybadin Planı'nda verilen imar haklarının artırımı yoluyla ve yık-yap süreçleri ile elde edilen bir süreçle kentin yeniden yapılanması sağlanmıştır. Bu dönemde Ankara hızla artan nüfusun barınacağı gecekondu kuşakları ile sarmalanmış, özellikle Ulus merkezi çevresinde düşük gelirli nüfusun yaşadığı bölgeler oluşmuştur. Kentin jeomorfolojik yapısı nedeniyle kuzey, güney ve doğu bölgelerinde yerleşime uygun olmayan yamaçlar gecekondu biçiminde yapılanmıştır. 1966'da çıkarılan 775 sayılı Gecekondu Yasası ile birlikte 1slah, tasfiye ve önleme politikaları geliştirilmiş, kent çevresindeki gecekondu alanlarının düzenli gelişme ile bütünleştirilmesi amaçlanmıştır.

Kentin hızlı nüfus atışı ile ortaya çıkan konut ihtiyacını düzenlemek ve mevcut kent üzerindeki yapılaşma baskısını azaltmak amacıyla 1969 y1lında kurulan Ankara Nazım İmar Plan Bürosu tarafından Ankara 1990 
Nazım Planı hazırlanmıştır. Yapısal ve kapsamlı planlama yaklaşımıyla elde edilen Plan ile nüfus projeksiyonuna bağlı olarak kentin ana gelişim yönü belirlenmiştir. Buna göre, kent jeomorfolojik yapının da uygun olduğu batı koridoru üzerinde gelişerek ana ulaşım sistemi doğrultusunda çalışma ve konut alanları yaratılmıştır. Benimsenen bu yaklaşımla birlikte, yeni konut alanlarının açılmasının gecekondulaşmayı engellemesi hedeflenmiş, ancak gecekondu olgusuna yönelik kapsamlı bir ele alış yakalanamamıştır. Kent bir yandan, oluşturulan batı koridoru üzerinde gelişirken, öte yandan, eski merkezi üzerindeki baskıyı azaltmak için Ulus Tarihi Kent Merkezi'ni koruyarak buradaki iş faaliyetini Kazıkiçi Bostanları bölgesine kuzeybatıya doğru yönlendirmiş (Erkal, Kıray ve Günay, 2005), ancak Ulus çevresinde yerleşen alt gelir gruplarının yerleşim biçiminde belirgin bir uygulama yapılmamıştır.

Ankara'nın sözü edilen planlama tarihi içinde Ulus, ilk planlama çalışmalarının çıkış noktasını oluştururken, sonraki dönemlerde kentin hızlı büyüme sorunsalı içinde önemini yitiren bir düğüm olarak kalmıştır. 1980 yılında Anıtlar Yüksek Kurulunun aldığ 12 . Derece Kentsel Sit kararıyla birlikte Ulus tarihi alanı belirlenmiş ve böylelikle alana yapılacak müdahaleler sınırlanmıştır. 1986 yılında Ankara Büyükşsehir Belediyesi'nin düzenlediği yarışma sonucunda birincilik kazanan Raci Bademli ve ODTÜ ekibinin önerisi esas alınarak 1987-1989 yılları arasında Ulus Planı hazırlanmıştır. 1989'da Ankara Kültür ve Tabiat Varlıklarını Koruma Kurulu'nun kararıyla 1/1,000 ölçekli Ulus Tarihi Kent Merkezi Koruma Islah İmar Planı uygun bulunmuş ve 1990 yılında Ankara Büyükşehir Belediye Meclisi tarafından onaylanmıştır. Raci Bademli yönetiminde hazırlanan ve 110 hektarlık bir alanı kapsayan plan uyarınca 'koruma, koruma ağırlıklı ıslah ve yenileme ağırlıklı ıslah' alanlarına yönelik program alanları geliştirilmiştir (Günay, 2005). Ulus Tarihi Kent Merkezi antik dönem, cumhuriyet öncesi dönem ve cumhuriyet dönemi Ankara'sı olarak tarihi katmanlar dikkate alınarak ayrıştırılmıştır. Plan sınırları içinde yer alan Çıkrıkçılar Yokuşu ve Saraçlar Sokak gibi ticaret alanları da belirlenen 19 adet proje alanı kapsamına alınmıştır. Ulus Planı farklı ölçeklerde arazi kullanımı, mülkiyet, yapılaşma, araç ve yaya dolaşımı, kamusal alan ve meydan düzenlemeleri, kent mobilyaları konularını bir bütün olarak ele alan katılımcılık ve müzakere yollarının geliştirildiği uygulamaya dönük bir strüktürel plan olma niteliği taşımaktadır. Planda korumanın sağlanabilmesinin doğru gelişme kararlarıyla yapılabileceği öngörüsü uyarınca korunması gereken alanlar üzerindeki kuzeybatı gelişme stratejileri ile azaltmak hedef- 
lenmiştir (Erkal vd., 2005). Buna göre, 1993 yılında kuzeybatıya doğru yönlendirilen gelişmeyi yönetebilmek için "Ankara Merkezi İş Alanı Planlama ve Geliştirme Proje Yarışması" düzenlenmiştir. Belediye yönetiminin değişmesiyle uzun sürecek bir planlama süreci sonunda onaylanan bu planla birlikte tarihi kent merkezi üzerindeki yüksek katlı yapılaşma ve yoğunlaşma baskısı azaltılmıştır. Sonuç olarak, Ulus Planı ile birlikte, merkezi gelişimin yönlendirilmesi, tarihi mülkiyet dokusunun yeniden oluşturulması, yeni imar haklarının verilmediği yapılarla mevcut dokunun korunması sağlanmıştır.

2005 yılında Ankara Büyükşehir Belediyesi (ABB) "ilk sit kararının alındığı 1980 yılından itibaren Ulus Tarihi Kent Merkezi'nde köklü değişim/dönüşüm sağlanamadığından mevcut dokudaki yapılar yıkılmaya, yıpranmaya yüz tutmuş, alan mezbelelik bir görünüm kazandığı" gerekçesiyle Ulus Planı'nı iptal etmiş, ve yerine "Ulus Tarihi ve Kültürel Kentsel Dönüşüm ve Gelişim Proje Alanı" oluşturmuştur (ABB, 2005). 2005 yılında 5366 sayılı yasanın yürürlüğe girmesinin ardından Büyükşehir Belediyesi'nce tarihi kent merkezi yenileme alanı olarak belirlenerek bu alanda yeniden koruma amaçlı imar planı çalışmaları yapılmıştır. Planda alt çalışma alanları oluşturulmuş ve tarihi ticaret bölgesi - Hanlar bölgesi, Samanpazarı ve Suluhan- olarak belirlenen geleneksel çarşıların bulunduğu alan için tarihi ticaret alanı yaklaşımı çerçevesinde varlıklarını sürdürerek kültürel ve turistik bir ekonominin yaratılması hedeflenmiştir (Günal, 2006). Ancak, Ankara 10. İdare Mahkemesi tarafından yenileme alanı sınırı, öngördüğü yıkımlar ve plan onama yetkisi sorunlarından dolayı Ankara Tarihi Kent Merkezi Yenileme Alanı 1:5000 Ölçekli Koruma Amaçlı Nazım İmar Planı ve 1:1000 ölçekli Koruma Amaçlı Uygulama İmar Planları'nın iptaline karar verilmiştir (Tunçer, 2013). Plan ve uygulamaların sürekliliğini sağlayacak kurumsal kapasitenin sınırlı olması ve yerel yönetimlerde benimsenen politika değişiklikleri nedeniyle, kentsel sit ilan edilen alanlarda koruma ve yenileme politikaları birbiriyle paralel olarak yürütülememiş; bu sınır içinde kalan alanda yapısal plan kararlarının yerini tekil müdahaleler almış ve günün koşullarına yanıt veren bir doku yaratılamamıştır.

Özetle, Kale çevresinde yer alan kentin tarihi alanlarının korunmasında süregelen planlama pratiğinde koruma yaklaşımı benimsenmiş olmasına karşın, bu alanlarda uygulamaya yönelik eylemler noksan kalmıştır. Alan bütüncül koruma kararlarının varlığına rağmen, yerel yönetim eliyle restorasyon, 1slah, tescil, yeniden işlevlendirme gibi parçacı ve tekil müdaha- 
lelerle şekillenmektedir. Bu haliyle, bireysel müdahale edilmesi zor ve gerekli kaynak aktarımından mahrum kalan alanlar, kendi haline bırakılmış olmanın ötesine geçememiştir.

\section{Tarihi Kent Merkezlerinin Kırılganlığı: Saraçlar Sokak Yangın Örneği}

Sosyal, ekonomik ve mekansal değeri olan tarihi kent merkezlerinin korunması önündeki risklerden biri de başta yangın olmak üzere alanın maruz kalabileceği doğal, beşeri veya teknolojik tehlikelerdir. Kent kimliğinin ve tarihsel olarak üretilmiş çevrenin sürdürülmesinde afet risklerine karşı korunmaları uluslararası politikaların da işaret ettiği gibi temel sorun alanlarından biri haline gelmiştir. Afetlere karşı kültürel mirasın korunmasında kültür varlıklarına yönelik riskleri yaratan nedenlerin belirlenmesinin sakınım ve müdahale politikalarının oluşturulmasına yol gösterdiği vurgulanmıştır. Ulus Saraçlar Sokak yangını örneğinden hareketle tarihi kent merkezinde kırılganlıkların nasıl üretildiği ve bu çerçevede tarihi alanlarda afet yönetiminin kırılganlıklara nasıl yanıt vermesi gerektiği soruları tartışılmıştir.

İş faaliyetini barındıran tarihi kent merkezlerinde kırılganlıklarını oluşturan nedenler bağlama ve yere özgü koşullara göre çeşitlenebilir (UNISDR, 2006). Afet yazınında kırılganlık bir toplumun, sistemin veya değerin afet zararlarına karşı kendisini hassas kılan özellikleri ve koşulları anlamına gelir. Pine (2009) kırılganlığı "sosyal, fiziki, ekonomik ve ekolojik sistemlerin zarar görme olasılığı" olarak tanımlanmaktadır (s. 136). Kentsel alanlardaki kırılganlıklar bu sistemlerin sürekliliği üzerinde hayati riskler üreten tarihi, sosyal, politik ve fiziki faktörlerden dolayı meydana gelir (Orhan, 2016; 2015). Hewitt'e (1983) göre toplumun geleceğini ilgilendiren kırılganlıklar geçmişten gelen sosyal eşitsizlikler ve sosyal ilişkilerin bir ürünüdür. 1980lerden bu yana afet çalışmalarında kırılganlıklar konusu önemli bir yer tutmakta olup özellikle kentsel sistemlerin kırılganlıkları üzerine odaklanılmaktadır. Beşeri aktivitelerin ve yerleşimlerin zarar görebilirlikleri araştırmalarında kültürel miras alanındaki çalışmalar yazında henüz yer edinmeye başlamış bir konudur. Hyogo Eylem Çerçevesi'nin uluslararası kabul gören kriterleri ve buna paralel gelişen koruma alanındaki anlaşmalarla tarihi alanlarda kırılganlıkların belirlenmesi yönetimler için bir yükümlülük haline gelmiştir. Kentsel sistemlerin kırılganlıklarını inceleyen kapsamlı çalışmalarında Bolin ve Stanford (1998) kırılganlıkları üreten etmenleri üç grupta tarif etmiştir; tarihi ve yapısal faktörler, 
sosyal özellikler, konumsal ve ekonomik etkenler. Takip eden çalışmalarda ve UNISDR'nın raporlarında $(2005 ; 2015)$ üzerinde uzlaşılan kırılganlık etkenleri kentsel nüfus artışı, sanayi yığılmaları, yasal olamayan yerleşimler, plansız kentleşme ve kurumsal kapasitenin yetersizliği olarak tanımlamıştır. Tarihi kent merkezlerinde kırılganlıkları oluşturan faktörler üç ana başlıkta incelenebilir; alanın tarihsel olarak üretilmiş mekânsal yapılanmasından kaynaklanan kırılganlıklar, kırılgan sosyo-ekonomik yapı ve iş faaliyetinden kaynaklanan kırılganlıklar (Şekil 1).

Şekil 1. Tarihi kent merkezlerinde kırılganlıkları oluşturan faktörler

\begin{tabular}{|c|c|c|}
\hline \multicolumn{3}{|c|}{ Tarihi kent merkezlerinin kırlganlıklan } \\
\hline $\begin{array}{l}\text { Mekansal yapi } \\
\text { - Yapılaşma biçimi } \\
\text { - Erişilebilirlik } \\
\text { - Altyapi }\end{array}$ & $\begin{array}{l}\text { Sosyo-ekonomik yapı } \\
\text { - Düşük gelir gruplan ve yere } \\
\text { gömülü ilişkileri } \\
\text { - Sinurlı sermaye birikimi }\end{array}$ & $\begin{array}{l}\text { İş faaliyetinin yapısı } \\
\text { - İşin niteliği } \\
\text { - Kullanıcı yoğunluğu } \\
\text { yaratma }\end{array}$ \\
\hline
\end{tabular}

$$
\begin{aligned}
& \text { Afetlerin tarihi kent merkezlerine olası etkileri } \\
& \text { - Tarihi dokunun zarar görmesi } \\
& \text { - Iş yerlerinin kapanması veya yer değiştirmesi } \\
& \text { - Düşük gelir gruplarının yoksullaşması } \\
& \text { - Kentsel kimliğin yitirilmesi }
\end{aligned}
$$

\section{Mekansal yapr}

İlk olarak, alanın tarihsel olarak üretilmiş mekansal örüntüsü niteliklerinden kaynaklanan kırılganlıklara bakıldığında, tarihi çarşılarda afet riski üretilmesine katkı koyan etkenler yapılaşma biçimi, fiziki çevrede erişilebilirlik ve altyapı ile ilgili olduğu görülmektedir.

Alandaki kentsel dokunun oluşma sürecinin Ankara'nın ilk yerleşim yeri olan Kale ve çevresi üzerinde gelişmelere dayandığ 1 görülmektedir. Tarihi iş alanı, Kale'nin güneybatısında yer almakta, eğimli bir alanda konumlanmaktadır. Topografyaya göre şekillenen sokakların çevresinde tek veya iki katlı ahşap yapıların yanı sıra planlama dönemlerinde açılan caddeler üzerinde betonarme yapılar yer almaktadır. Sokak genişliği ve yapıların sokak üzerinde konumlanması bakımından geleneksel Anadolu kenti dokusu sergilemektedir. Alanda yer alan tarihi yapılar ve ahşap binalar alanın risk düzeyini artırmaktadır. 1950lerden itibaren bu alandaki yapıların işlevlerinin konuttan işyerine dönüşmesi bu tarihi ve ahşap yapılar üzerindeki baskıyı artırmaktadır. Özellikle ahşap yapılarda yangın 
tehlikesinin yaratacağı kayıplar betonarme yapılara kıyasla oldukça yüksektir.

Alan tarihsel yapısı ve eğimli alandaki konumu nedeniyle organik bir yerleşim düzeni örneği oluşturmaktadır. Alanın dolu-boş ilişkileri ve yapıların bir araya gelerek ürettikleri biçim taşıt erişilebilirliğini kısıtlamaktadır. Yol genişliği, sokakların birbirlerine bağlanma açıları, yol açıklıklarının süreksizliği ve bağlantı noktalarının tanımsızlığı alanın erişilebilirliği bakımından sınırlayıcı ve risk artırıcıdır.

Tarihi kent merkezindeki iş alanları, Ankara'nın toptan ve perakende tekstil sektörü içinde önem taşımaktadır. Perakende alışveriş yapan müşteri profili alanda yoğun bir yaya trafiği yaratmaktadır. İşyerleri gün içinde kullanım yoğunluğu oluşturmakta, böylece alan hareketli bir nüfus topluluğu barındırmaktadır. Ancak, gün içinde yoğunlaşan nüfusun olası bir afet karşısında toplanabileceği açık alanlar bulunmamaktadır. Buradaki kentsel doku, yaya dolaşımı açısından da sokakların süreksizlikleri ve açık alan yetersizlikleri nedeniyle alanın risklerini artırmaktadır.

Öte yandan, alanın mekansal yapısından kaynaklanan bir diğer kırılganlık etkeni altyapı ile ilişkilidir. Belirtildiği gibi, alanın süregelen tarihi çevresi içinde yapısal dönüşüm ve iyileştirmeler yapılamamıştır. 1950li yıllarda başlayan konuttan işyerine dönüşüm süreci içinde ortaya çıkan altyapı gereksinimleri karşılanamamış, erişilebilirlik konusunda da görülen yetersizlikler altyapı alanında da oluşmuştur. Alanın afet riskleri bakımından ihtiyaç duyduğu altyapı sunumu yangına müdahale edebilecek su depolarıdır. Bu depolar, 2000lerde yerel yönetim eliyle alana konumlandırılmış olmasına karşın düzenli bakım ve tedarik yapılmadığı için meydana gelen yangında su depolarından söndürme ihtiyacı karşılanamamiştır.

Bu sebeplerden dolayı, meydana gelen yanginda, itfaiye aracı yangının çıktığı işyerlerinin bulunduğu sokağa doğrudan girememiş, alana ulaşmak için Anafartalar Caddesi üzerinde konumlanmıştır. Müdahale, yaya merdivenleri ve sokak boyunca araçtan uzatılan söndürme hortumu ile yapılabilmiştir. Yangının gece saatlerinde meydana gelmesi alanda kullanıcı yoğunluğu ve yaya trafiğinin bulunmaması dolayısıyla olası tahliye edilme ve beraberindeki problemlerin yaşanmamasına yol açmıştır.

\section{Sosyo-ekonomik yapt}

İkinci olarak, alanın sosyo-ekonomik yapısındaki kırılganları oluşturan etkenlere bakıldığında, tarihi kent merkezinin kullanıcılarının özellikleri- 
nin ve burada süregelen ekonomik ve kurumsal yapının değerlendirilmesi gerekir. Alanın sosyo-ekonomik özellikleri bölümünde de bahsedildiği gibi, Çarşı'nın temel müşteri profilini kent alt gelir gruplarında yer alan hanehalklarının oluşturduğu bilinmektedir. Çarşı alt gelir grubundaki hanehalklarının kullandığı merkezi alan niteliği taşımaktadır.

1980 sonrası kentlerin yaşadığı yapısal dönüşümden en çok etkilenen kent merkezlerinin işlevlerinin bir bölümü kent dışındaki, çeperlerindeki alanlara kaymıştır. Öte yandan, gelişmekte olan ülkelerin temel sorunlarından olan eşitsiz sermaye birikimi nedeniyle sanayileşmenin getirdiği kentsel nüfus artışı düzenli biçimde yerleştirilememiştir. Gecekondu olgusu bu gelişme içinde değerlendirilmelidir. Ankara kentinde demiryolunun fiziksel bir ayırıcı rolünü üstlenmesiyle eski ve yeni kent merkezleri etrafında oluşan gecekondu alanlarının kaderleri de birbirlerinden farklı olmuştur. Güneyde, yeni merkez çevresinde oluşan gecekondu alanları yüksek arsa rantları nedeniyle 1980 sonrası kentsel dönüşüm politikalarıyla yeniden yapılanmıştır. Ancak, kuzeyde eski merkez çevresindeki düşük gelir gruplarının oluşturduğu gecekondu alanlarının dönüşümü 2000lerde başlamıştır. Bu döneme kadar, düşük gelir gruplarının yaşam alanlarıla çevrelenmiş tarihi merkez bir yandan yapılaşma baskısıyla işlevlerini sürdürürken, diğer yandan koruma planlarının uygulanmamasından dolayı yeniden yapılandırılamamıştır. Tarihi alan, kullanıcıların sınırlı dönüştürme kapasiteleri ve planlama kararlarının karar verici ve uygulayıcılar tarafından göz ardı edilmiş olması sonucu varlığını bütüncül müdahalelere konu olmadan sürdürmüştür.

Ek olarak, 1990lardan bu yana üst gelir grubunun kent dışına taşınması hızla artan çeperleşme, merkezi fonksiyonların yayılma eğilimi ve merkezin cansızlaşması sorunlarını doğurmuştur. 1990 Ankara Nazım Planı'nda verilen Batı koridorunda gelişme kararıyla orta-üst ve üst gelir grupları kentin çeperinde yerleşmeye başlamıştır. Bu dönemde taşıt sahipliliğinin artması ve koridor üzerinde yeni yaşama ve çalışma alanlarının yaratılmas1, kent merkezinin bazı fonksiyonlarının Ulus-Kızllay ekseninden batı eksenine taşınmasına yol açmıştır. Özellikle, üst gelir gruplarının yer değiştirerek çepere yayılması ve yeni yerleşim alanlarında oluşturulan alt merkezlerde ticaretin örgütlenmesi merkezi işlevlerin desantralizasyonuna neden olmuştur. Satın alma gücünün yer değiştirmesi ile yeni tüketim biçimleri ve alanları oluşmuş, koridor üzerindeki tüketim odakları haline gelen alışveriş merkezleri kent merkezinin çekiminin azalmasına katkı sağlamıştır. Diğer taraftan, yeni tüketim odakları ve alışveriş merkezleri- 
nin kent merkezinin gelişimi karşısında yarattığ tehdit sermaye birikiminin sınırlı olduğu eski kent merkezi için benzer şiddette yaşanmamıştır. Alanın alt gelir gruplu kullanıcıları için Ulus hala canlılığını korumakta olan bir merkezdir ve geleneksel merkezi işlevlerini sürdüren tarihi kent çarşıları zaman içinde önemli bir ölçüde değişmemiştir.

Bahsi geçen kentsel gelişim ve dönüşüm politikaların sonucunda alanın kullanıc kitlesinin baskın biçimde alt gelir gruplarının oluşturduğu görülmektedir. Alan kullanıcılarının tarihi kent merkezini ulaşım maliyetleri ve alanın sunduğu fiyat politikaları nedeniyle tercih ettiği ve alternatif alışveriş mekanlarına yönelmediği düşünülebilir. Bu durum, kullanıcıların yere gömülü̈ ${ }^{1}$ ilişkiler kurması sonucu doğurmuştur. Yere gömülü ilişkiler, alanın kullanıcı profili tarafından belirlenmesine yol açmaktadır. Tarihi iş alanında bulunan ürün ve hizmetler de kullanıcıların ihtiyaçlarını ve geleneksel sosyo-kültürel yapısını karşılayacak çeşitlilikte sunulmaktadır. Bu nedenle, iş faaliyetleri ve kullanıcı arasında yerin tanımladığ ilişkilerin belirleyici olduğu sonucu çıkarılabilir. Tarihi kent merkezindeki iş faaliyetlerinin afetlerden dolayı uğrayabileceği olası kesinti ve zararlar, en kırılgan gruplardan biri olan alt gelir grupları açısından da risk oluşturmaktadır. Benzer şekilde, alt gelir grupları yoğunlukla kullandıkları tarihi iş alanını iyileştirme, yenileme ve ıslah etme potansiyeli yaratacak birikimi ortaya çıkaramamıştır. Alanda yer alan işyerleri de bulundukları çevreyi fiziki ve mekansal bakımdan yenileyebilecek birikime sahip olmadığından alan üretilen risklerle karşı karşıya kalmaktadır.

Yerel sermayenin yanı sıra, kurumsal kapasite yetersizliği de alanın afetlere karşı dirençli kılınması önündeki engellerden biridir. Tarihi kent merkezinde bütüncül planlama yaklaşımı ile üretilen koruma ve gelişme kararlarının bulunmasına rağmen yerel yönetimlerin planları iptal etmesi plan sürekliliğinin sağlanamaması ve tekil uygulamaların başlamasına neden olmuştur. Böylece, tarihi çevrede parçacı yenileme çalışmaları kapsamına dahil edilmemiş alanlar sistematik ve planlı bir gelişmeden yoksun kalmıştır. Öte yandan, kentsel sit kararı bulunan alanda yapılacak müda-

\footnotetext{
${ }^{1}$ Yere gömülülük (spatial embeddedness); bölgelerin yere ait kümelenmiş sosyal ve ekonomik ilişkilerini tanımlayan kavramdır. Ekonomik coğrafya ve bölge planlama alanında yerele ilişkin yaratıcı ortam, içsel bilgi ve kurumsal yapının bir aradalığının getirdiği avantajlı pozisyonu tanımlamak için kullanılmaktadır (Scott, 1988; Storper, 1997; Amin, 1999). Metinde, toplumun yere özgü sosyal ve ekonomik ilişkilerinin mekanı yapılandırmasını ve mekanla birlikte yapılanmasını ifade etmektedir. Karşlıklı belirlenme durumuna işaret etmektedir.
} 
haleler belirli bir yasal çerçeve içine alınmıştır. Bu denetim mekanizmasına bağlanan tarihi merkezinde kalan alanların tekil fiziki müdahalelerle yenilenmesi mümkün değildir. Kamu yönetiminde değişen politik yapının plan kararlarını değiştirmesi, sınırlı sermaye birikimi ve kurumsal kapasite yetersizliği, tarihi alanın afetlere karşı kırılganlıklarını artırmaktadır.

\section{İs faaliyetinin yapısı}

Üçüncü ve son olarak, tarihi kent merkezinin afetlere karşı kırılganlıkları artıran etmenlerden biri de alanda sürdürülen iş faaliyeti ile ilişkilidir. İş faaliyetlerinin alanda yol açtığı riskler barındırdıkları işyeri özellikleri ve alanda yoğunluk artırıcı rol oynaması nedenleriyle açılanabilir.

Tarihi alanın kullanıcıları, diğer bir deyişle perakende alışveriş yapan müşteriler, ihtiyaçlarının temininde tarihi iş alanının sunduğu ürün çeşitliliğinden yararlanmakta ve mekânsal örüntünün imkan verdiği biçimde yaya akışı yaratmaktadır. Ağırlıkla tekstil ürünlerinin satıldığı manifatura, tuhafiye, perde, hazır giyim ve ev tekstili firmaları yer almaktadır. Bunun yanı sıra, alanda halıc ve mobilyacılar, elektrikli cihaz ve malzemeciler, nakliyeciler, inşaat malzemeleri satıcıları, hurdavatçılar, inşaat müteahhitleri, hazır ayakkabı imalatçıları, kırtasiyeciler, eczacılar, makine ve madeni eşyacıları, matbaacılar, fotoğraf malzemesi satanlar, hurdacılar, nalburlar, kuyumcular, saraciye imalatçıları, tıbbi cihaz satıcıları, tabutçular, bakırcılar, tahta oymacıları ve benzeri faaliyet kolları bulunmaktadır.

Alanda 1950li yıllardan bu yana konuttan işyerine doğru bir dönüşüm yaşanmaktadır (Cengizkan, 2006, s.32). Özellikle, Ulus, Samanpazarı ve Anafartalar Caddesi üzerinde yoğunlaşan ticaret kullanımları görülmektedir. Bu kullanımlar zaman içinde yapılan restorasyon çalışmaları sonrasında yaygınlaşmış ve yalnız Ulus ekseninde değil, Kale içine kadar uzanmıştır. Süregelen tarihi dokunun içinde oluşan iş faaliyetinin gerektirdiği altyapı ihtiyacı karşılanamamıştır. İşyerlerinin sahip oldukları nitelikler ve gün içinde nüfus yığılmalarını çekmeleri alanın kırılganlı̆̆ını artırıcı rol oynamaktadır.

Yazında, işyerlerinin hanehalkları gibi afetlerden kırılganlıklarının ve afetler karşısında verdikleri yanıtların birbirlerinden farklılaştı̆̆ı ortaya konmuştur (Alesch, Holly, Mittler ve Nagy, 2001; Webb, Tierney ve Dahlhamer, 2002; Tierney ve Webb, 2001; Chang ve Falit-Baiamonte, 2002). Yapılan çalışmalar, işyerlerinin kırılganlıklarını belirleyen faktörlerin işyeri büyüklügü̈, sektörü, işyeri yaşı, mali durumu, mülkiyet durumu, pazar veya piyasa büyüklüğü, işyeri sahibi veya yöneticisinin eğitim durumu, ve 
afetlere karşı hazırlık düzeyi ile ilişkili olduğunu koymuştur (Tierney, 1994, 1997; Nigg, 1995; Dahlhamer ve Tierney, 1998; Webb, vd., 1999; Alesch, vd., 2001; Tierney ve Webb, 2001; Chang ve Falit-Baiamonte, 2002; Zhang, Lindell ve Prater, 2009; Powell ve Harding, 2009). Özellikle, yanıcı ve patlayıcı materyallere ve stoka sahip işyerlerinin bulundukları alanın kırılganlıklarını arttırdığını söylemek mümkündür. Farklı niteliklere sahip olan işyerlerinin afetlere karşı kırılganlıklarının değişkenlik göstermesinin yanı sıra bu işyerlerinin bulundukları alanı da etkileyecek şekilde farklı iyileşme yolları izlediği saptanmıştır (Dietch and Corey, 2011; Wasileski, 2011). Bununla birlikte, literatürde afetlerin işyerlerini aldığı hasarın büyüklüğü, hazırlıklı olma durumu ve kırılganlık düzeylerine bağlı olarak çeşitli şekillerde ve şiddette etkilediği ortaya konmuştur. Afet maruz kalan işyerlerinin iş faaliyetine ara verme, iş faaliyetini başka bir alanda sürdürme, iş faaliyetini sonlandırma, işi küçültme, sektör değiştirme ve mali yardım alma yollarına başvurdukları görülmektedir. Farklı iyileşme senaryoları izleyen işyerlerinin özellikle yer değiştirme, uzun kapalı kalma süresi gösterme veya kapanmaları nedeniyle alanın afetlere karşı kırılganlıkları artmaktadır. Özellikle Ulus Tarihi Kent Merkezi gibi alt gelir grubunun kullanıcıların oluşturduğu alanlarda işyerlerinin farklı iyileşme stratejilerine karşı kullanıcıların yoksullaşma eğiliminin yükselmesi söz konusudur; diğer bir deyişle işyerleri niteliklerinden kaynaklanan sebeplerle alt gruplarının kırılganlıkları artabilir.

Saraçlar Sokak'ta meydana gelen yangından dört gün sonra yapılan saha incelemesinde yangından doğrudan ve dolaylı olarak zarar gören işyerleriyle görüşme gerçekleştirilmiştir. Bu işyerlerinin sözü edilen etkenlere göre tarihi kent merkezindeki iş faaliyetleri nedeniyle alanda ortaya çıkan zararların ve bu zarara yol açan kırılganlıkların tespit edilmesi amacyyla bir değerlendirme yapılmıştır. Yangının başladığı yapıda ve çevresinde yer alan dört işyeri sahibine ulaşılamamış; yangından doğrudan etkilenen üç ve dolaylı etkilenen üç firma olmak üzere toplam altı işyeri sahibi ve çalışanıyla görüşmeler yapılmıştır. Yangından doğrudan zarar gören 7 işyeri yer almaktadır. Yangından etkilenen işyerleri ayakkabı ve tekstil ürünleri sunan perakende ve toptan ticaret sektöründe yer almaktadır. Toptan ticaret ile uğraşan bir firmanın 15 çalışanı olduğu, diğer altı firmanın perakende sektöründe olduğu ve bunların 10 ve daha az çalışanı bulunduğu bildirilmiştir. Firmaların alanda 1950lerden beri var olduğu, alandaki yapıların gecekondu statüsünde yer aldığı, yangın öncesinde işlerinin iyi olmadığını ve bankalarda kredi borçlarının bulunduğunu belirtilmiştir. Toptan ticaretle uğraşan firmanın alan dışında da ürün sundu- 
ğu firmalar olduğu, perakende ticaretle uğraşan firmaların ise Çarşı müşterileriyle sinırlı bir pazar potansiyeli olduğu öğrenilmiştir. Alandaki firmalar zincir bir işletme modelinin parçası olmayıp, tamamı tekil firma statüsündedir.

Yangından en çok zarar gören firmalar, yangından doğrudan etkilenen işyerleridir. Bu işyerlerinin uğradıkları hasar tiplerine bakıldığında, faaliyetlerini sürdürdükleri yapıların elemanlarında (çatı, pencere, kapı, vb.) hasar olduğu; stokun ve ofis ekipmanlarının zarar gördüğü; çıtı, hizmet veya ara mal sunulamadığı; ve müşteri kaybı sorunları yaşadıkları gözlenmiştir. Yangından dolaylı etkilenen işyerlerinin ise aldığı hasar tipleri, stokun zarar görmesi; altyapı sistemindeki kesintiler (elektrik); ve alana erişim problemleri olarak saptanmıştır. Yangından doğrudan etkilenen tüm firmalar gördükleri hasar nedeniyle iş kesintisi yaşamakta olup, dolaylı olarak etkilenen firmalar kapalı kalmayıp, zarar gören stok dahil olmak üzere ürün satışlarını sürdürmektedir. Alandaki ahşap yapıların yüksek risk taşıması, betonarme olanların ise ruhsatsız olması, işyerlerinin sigorta kapsamına alınmasını engellemiştir. Yapıları üzerinde herhangi bir afet sigortası olmayan işyerlerinin başka afete hazırlık ve önlem alma yönünden yetersiz kaldıkları görülmektedir. Sigorta yaptırmayan işyerlerinin oluşan zararı telafi etmek için kaynak yaratması ancak borçlanma yoluyla veya kişisel birikim ve işyeri rezervlerini hareket geçirerek mümkün olacaktır. Öte yandan, zarar gören firmalar arasında, afet sonrasında hizla iş faaliyetlerini sürdürmelerini sağlayacak başka bir yer seçim imkanı bulunmamakla birlikte bu karar yerel yönetimlerin yönlendirmesinin dışında işyerlerinin iyileşme süreçleri içinde alacakları bireysel yer seçim kararları doğrultusunda verilecektir. Benzer şekilde, acil durum müdahale sonrasındaki dönemde yerel veya merkezi yönetimlerin alanın iyileştirilmesine yönelik mekansal veya fiziksel düzenlemesi olmamıştır. Alan kolluk güçleri tarafından güvenlik şeridi ile ayrılmış olmasına rağmen işyeri sahipleri ve kullanıcılar tarafından yapıların çökme riskine karşın kullanılmaya devam etmiştir.

Balamir'e (2007) göre kentsel alanda afetlerin tetikleyebileceği bir dizi risk sektöründen biri alanda bulunan tehlikeli birim ve kullanımlardır. Saraçlar Sokak örneğinde alandaki işyerlerinin yangını tetikleyici faaliyetlerinin tarihi mekânsal dokuya zarar verme riski bulunmaktadır. Ayrıca, alandaki iş kollarının acil durumda ve afet sonrasında ihtiyaç duyduğu teknik altyapı imkanlarının da kısıtlı olduğu görülmektedir. Olası bir afet karşısında tescilli ve korunması gereken yapıların kaybedilme riski doğ- 
maktadır. Bununla beraber afet anında kullanıcı yoğunluğunu dağıtabilecek kanalar ve toplanma imkanı sunan açık alanlar yetersizliği alanın iş faaliyetinden kaynaklanan kırılganlıklarını artırmaktadır.

Özetle, tarihi kent merkezi, alandaki iş faaliyetleri, kullanıcı yoğunluğu, altyapı ve ulaşım kısıtları ve yapılaşma biçimleri nedeniyle doğrudan; kentin büyüme sürecinde alt gelir gruplarının yer seçimi, sınırlı sermaye birikimi, yere gömülü ilişkiler, bütüncül koruma planlarını yapma ve uygulamadaki kurumsal kapasite yetersizliği nedeniyle dolaylı olarak kırılgan hale gelmiştir.

\section{Tartışma: Tarihi Kent Merkezlerinde Afet Yönetimine Yönelik Politikalar}

1980 sonrası dönemde küresel politikalar ve yabancı sermayeli yatırımların çekilmesi ihtiyacı ve 1990 Nazım Planı'nın kent merkezindeki yapılaşma baskısını yönlendiren kararları doğrultusunda Ankara'da iş faaliyetinin mekansal yapılanma biçimleri değişiklik göstermiştir. Üretim birimleri organize sanayi bölgeleri biçiminde örgütlenerek kent çeperine taşınmakta, ofis kullanımları geniş bir alana yayılmakta, ticaret ise ana ulaşım eksenleri üzerinde bir araya gelerek yer seçmektedir. Ancak, tarihi kent merkezi içinde yer alan ve geleneksel üretim ve ticaret etkinliklerini sürdüren işyerlerinin yeni yer seçim olanaklarının kısıtlı olmasının yanı sıra bulundukları alanı dönüştürme kapasiteleri de sınırlıdır. Tarihi kent merkezinin barındırdığ 1 iş faaliyeti ve alanın alt gelir gruplarından oluşan kullanıcıları göz önüne alındığında, bu alanda afetlerin yol açacağı kayıp ve hasarın kentte yaratacağı etki yalnızca etkilenen işyerinin sorunu olmayacak, aynı zamanda sosyo-mekansal bir problem ortaya çıkaracaktır.

Tarihi kent merkezinde afetlerin tetikleyeceği kayıpların başında tarihi dokunun zarar görmesi yer almaktadır. Tarihi kentsel alan yasal zeminde koruma altında olmasının yanı sıra afet risklerine karşı dirençli hale getirilmeleri yerel ve merkezi yönetimlerin görevleridir. Ek olarak, afetlerin etkilerinden dolayı tarihi kent merkezlerinde iş faaliyetinin sonlanması ve işyerlerinin alan dışında işini örgütlenmesi sorununa yol açabilir. Bu durum özellikle yere gömülü ilişkileri bulunan alt gelir gruplarının yoksullaşması problemini doğuracaktır. Tarihi kentler alanlarda bahsi geçen kayıpların oluşması alanda üretilen sosyal pratiklerin, toplumsal belleğin ve kent kimliğinin yitirilmesine neden olacaktır.

Bu sebeplerle tarihi kent merkezlerinin korunması ve afetler karşısında dirençli kılınması temel kamusal sorumluluklardan birisidir. Afet yöneti- 
minin uluslararası düzlemde üretilen politikalara uygun biçimde çağdaş yaklaşımlarla ele alınması ve UNISDR ve UNESCO gibi uluslararası örgütlerin öncülük ettiği gibi korunması gereken alanlarda risk azaltmaya yönelik politikalar oluşturulması gereklidir. Afete maruz tarihi kent merkezlerine yönelik kapsamlı risk azaltma stratejisinin temel bileşenleri aşağıda özetlenmiştir;

1. Haritalama ve envanter hazırlama;

- Belgeleme ve tespit: Önceliklendirme ve müdahale çalışmalarına altlık oluşturulmak için tarihi kent merkezlerinin bulunduğu alanın haritalanması gereklidir.

- Analiz ve sinıflandırma: Alanda yer alan yapılar bina türlerine, işlevlerine göre sinıflanmalı, bu sinıflandırma haritada gösterilmelidir. Yine haritalar üzerinde işyerleri ve barındırdıkları tehlikeli kullanımlar işaretlenmelidir. Yanıcı, patlayıcı madde içeren işyerlerinin konumları ve çevredeki diğer kullanımları ilişkileri belirlenmelidir. Alanın yol sistemi ve altyapı elemanları belirlenerek yine haritalara aktarılmalıdır.

2. Sakınım Planlamasi;

- Tehlikelerin belirlenmesi: Sakınım planlaması tarihi iş alanlarının maruz kalabilecekleri çoklu afet türlerine göre hazırlanmalıdır. Başta yangın olmak üzere deprem ve sel gibi tehlike türlerinin yer aldığı senaryolar üzerinden bu afetlerin yol açabileceği olası kayıplar tanımlanmalıdır.

- Gelişme kararlarının verilmesi: Tarihi dokudaki yapılaşma baskısını azaltmak, gelişme talebini yönlendirmek ve mevcut dokuda altyapı ihtiyacı karşılayacak açık alan yaratmak için kent merkezindeki gelişmeyi yönlendirecek kararlar verilmelidir.

- Yenileme, koruma ve yapılaşma koşullarının belirlenmesi: Alanda yapılaşma baskısını azaltacak bütüncül plan kararları alınmalıdır. Tarihi kent merkezine ek yoğunluk getirecek yeni yapılaşmadan ve alanın tarihsel dokusuna uyumsuz imar haklarından kaçınılmalıdır.

- Afet anında müdahale etme olanakları: Alana afet anında müdahale edilmesine olanak sağlayacak yol ve altyapı elemanlarının mevcut durumu tespit edilmeli, acil durumda ihtiyaç duyulacak alternatif güzergahlar, erişilebilir açık alanlar ve altyapı sistemleri tasarlanmalıdır. Özellikle, tarihi kentsel dokularda dar ve merdivenli sokaklarının engelli, yaşlı ve çocuklu bireylerin kullanımına yönelik tasarlanması gerekmektedir. Alanda yer alan acil durum işlevindeki yapıların (hastane, itfaiye, vb.) erişilebilirliklerini artırmak amacıyla, yol veya kamusal açı alanlarla doğrudan bağlantıları kurulmalıdır. 
- Komşuluk ilişkilerinin tasarlanması: Alandaki tehlikeli kullanım barındıran işyerlerinin yer değiştirmesini sağlamak amacıyla bu işyerleri için kullanıcıların da erişebileceği yeni alanlar sunulmalıdır. Tehlikeli kullanım bulunduran işyerlerinin yerleşim alanlarıyla komşulukları ve tarihi dokudaki yeri göz önüne alınmalıdır.

- Sosyal kırılganlıkların anlaşılması: Alanın kullanıcılarının sosyoekonomik düzeyleri göz önüne alınmalı, özellikle en kırılgan alt gelir gruplarının kullandığı alanlarda iş faaliyetinin sonlanmasının veya yer değiştirmesinin yaratacağı olumsuzluklar göz ardı edilmemelidir.

- Farkındalık: Tarihi çarşı içinde yer alan işyerlerinin önlem almaları ve afete hazırlık düzeylerinin artırılması için düzenli eğitim verilmelidir. Yerel yönetimler, işyerlerinin sigorta yaptırmalarını teşvik edecek uygulamalar geliştirmelidir.

- Katılımcılık: Sakınım planlarının yalnızca teknik bir ele alışın ürünü olmaması için alan kullanıcıları, işyeri sahipleri, sivil toplum ve meslek örgütleri, yerel yönetimler ve akademinin katılımıla birlikte üretilen ve uygulanan bir süreç olarak tasarlanması gerekmektedir.

3. Önceliklendirme;

- Tarihi iş alanlarında risklerin azaltılması için yapılan planlama çalışmalarında, tahsis edilen kaynakların etkin kullanımı için yapılacak yatırım ve müdahalelerin akılcılaştırılması gerekir. Buna göre, müdahale edilecek alan ve yapılar arasında önceliklendirme yapılmalıdır.

- Önceliklendirme politikalarının belirlenmesinde hazırlanan envanter anahtar rol oynamaktadır. Buradan hareketle, ilk olarak, koruma altındaki veya korunma değeri taşıyan yapıların kentteki varlığını sürdürmek amacıyla bu yapıların güçlendirilmesi ve yapının kendisinde ve çevresinde tehlikeli kullanım barındıran iş faaliyetlerinin sınırlandırılması gerekir.

- Okul, hastane, müze gibi yapıların, kamusal kullanımlar olmaları nedeniyle ve acil durumlarda kullanılmak üzere yine öncelikli olarak güçlendirilmeleri gerekmektedir.

- Tarihi iş alanlarının sahip oldukları sınırlı altyapının güçlendirmesi ve bakım ve onarımlarının düzenli hale getirilmesi gerekmektedir. Kentin bu alanlarına hizmet eden su depoları, boru hatları, telefon santralleri ve elektrik şebekeleri gibi önemli tesislerinin güçlendirilmesi ve olası bir afet anında kullanılabilir kalmaları gerekmektedir.

4. Acil durum ve müdahale politikalarl;

- Yerel yönetimlerin tarihi çarşılarda meydana gelebilecek bir afete müdahale edebilecek donatılara (personel ve ekipman) sahip olması gere- 
kir. Kullanılacak müdahale ekipmanlarının alanın özellikleri göz önüne alınarak seçilmesi gerekmektedir. Buna göre, müdahale ve kurtarma araçlarının ve alanda oluşabilecek hasarı kaldıracak ağır makinelerin tarihi alana girebilecek ve yapılara zarar vermeyecek büyüklükte olmasına özen gösterilmelidir.

5. İyileştirme politikaları;

- Afet sonrası iyileştirme sürecinde zarar görmüş işyerlerinin alan kullanıcıları ve kent kimliğinin korunması kaygılarıyla alan dışına itilmemesi için politikalar üretilmelidir.

- Afet sonrasında işyerlerinin kendiliğinden bir yer seçim kararı üretmesi sonucunda alandan ayrılma ve alanın niteliksizleşmesi sorunu doğabilir. Bu nedenle, iyileştirme sürecinde işyerlerine yer seçim alternatifleri sunulması merkezi alan gelişiminin kontrol edilmesine yardımcı olacaktır. Bunun için sakınım planıyla üretilen alternatif gelişme alanlarına yönlenilmelidir.

- Afet sonrası iyileştirme müdahalelerinin temel amacı alanın afet öncesi durumdan daha güçlü kılınmasıdır; bu nedenle ilerde olası bir afetin sonuçlarıyla baş etme kapasitesinin yaratılması ve desteklenmesi hedeflenmektedir. Bunun için, zarar görmüş işyerlerinin mali borçlarının ertelenmesi ve destek kredileri yaratılması gerekir.

\section{Sonuç}

Ulus Tarihi Kent Merkezi barındırdığı işlevler ve süregelen mekânsal dokusuyla Ankara'nın tarihsel kimliğinin değerli bir parçasıdır. Kullanıcıları olan alt gelir grupları alanın sunduğu merkezi işlevlere karşı duyarlıdır. Kullanıcıların, konut, çalışma ve alışveriş alanları arasında seçenek üretemediği ve alanda dönüşüm ve korumaya yol açamadığı görülmektedir. Üst gelir gruplarının sermeye dolaşımını dolayısıyla merkez fonksiyonlarını çekebilme yetisinin aksine, düşük gelir gruplarının yere gömülü yapısı ve kısıtlı hareketliliği nedeniyle tarihi iş alanlarının varlığı hem kentsel mekan hem ekonomi hem de sosyal yapı açısından önem taşımaktadır.

Tarihi iş alanları kentlerin eski merkezleri içinde kalan ve kent kimliğini tanımlayan öğelerdir. Eski kent merkezleri mekânsal yapısı, sosyoekonomik koşulları ve barındırdıkları iş faaliyetleri nedeniyle afete açık hale gelmektedir. Tarihi kent merkezlerinde işin sınırlı pazar olanakları ve sınırlı iktisadi koşulları nedeniyle de afet sonrası süreçte karşılaştıkları sonuçlar ağır olmaktadır. İyileşme sürecindeki sıkıntılar nedeniyle tarihi 
alanda yer seçmiş işin çöküşü mekânsal niteliklerin yitirilmesini hızlandırmaktadır.

Geleneksel iş çevresine ev sahipliliği yapan Ulus Tarihi Kent Merkezi'nin karşılaştığı yangın deneyimi, tarihi alanlarda yer alan işyerlerinin nüfus yoğunluğu yaratması ve tehlikeli kullanımlara ev sahipliği yapması nedeniyle alanın risklerine katkı koyduğunu göstermiştir. Bir yandan, kentin alt gelir grupları düşük hareketliliği ve yere gömülü ilişkileri nedeniyle alanla bağımlı bir ilişki kurup ekonomik canlılığı yaratırken, diğer yandan sinırlı sermaye birikimi ve yetersiz kurumsal kapasite alanda gerekli müdahalenin yapılmasını ertelemiş ve tıkanmış bir kent parçası yaratmıştır. Tarihi çarşıdaki işyerleri için kapanma veya yer değiştirme afetin tetiklediği bir seçenek olduğundan, bu alanın bağımlı ilişkilerinin kopması ve geleneksel iş merkezi fonksiyonunun kaybı sorunları doğacaktır. Buradaki işyerleri alanın korunmasına katkı vermektedir. Bu nedenle, kamusal sorumluluk adına yerel yönetimlerin tarihi çarşılara yönelik kapsamlı bir afet yönetimi anlayışı geliştirmesi beklenir. Yapılan çalışma, tarihi kent merkezlerinde kırılganlıkları oluşturan etmenlerin neler olduğunu ve afet yönetiminin nasıl ele alınması gerekliliğine yönelik bir politika önerisi ortaya koymaktadır. Takip eden çalışmalarla, tarihi alanların farklı afet türlerinden nasıl etkilendiği araştırılmalı, tarihi alanlarda zarar gören işyerlerinin nasıl bir iyileşme süreci yaşadığı ve bunun bir parçası olarak nasıl bir yer seçim kararı aldıkları incelenmelidir. Böylece, yerel yönetimlerin afet yönetiminde izleyecekleri politikaların somutlaşmasına katkı konulabilecektir. 


\title{
Extended Abstract
}

\section{An Overview on Vulnerability and Disaster Management of Historical City Centers: The Case of Ankara Saraclar Street Fire}

\author{
Ezgi Orhan \\ Çankaya University
}

One of the main problems of historical urban areas is natural, human or technological disasters. The concern on conservation of cultural heritage was taken into agenda after the end of the Second World War; and with the initiations of UNESCO, principals related to protection and rehabilitation of cultural heritage were identified. Disaster management approaches for protection of cultural heritage has been developing with contributions at international level since Hague Convention (1954). Particularly, UNESCO World Heritage Committee accepted the Strategy for Risk Reduction at World Heritage Properties and identified the policies addressing disaster risk reduction. The international framework put forward the need for identification of underlying risk factors and policies to reduce them. Additionally, UN Secretary-General for Disaster Risk Reduction is committed to coordinate international efforts in disaster risk reduction. As a significant policy document accepted at international level, Hyogo Framework for Action 2005-2015 underlined that culturally important lands and structures should be protected and strengthened through proper design, retrofitting and re-building. Also, Sendai Framework for Disaster Risk Reduction 2015 - 2030 determined cultural heritage as priority areas by claiming that "it is important to systematically evaluate, record, share and publicly account for disaster losses and understand the economic, social, health, education, environmental and cultural heritage impacts, as appropriate, in the context of event-specific hazard-exposure and vulnerability information". In this respect, this study aims to develop a policy 
guideline for disaster management of business districts in historical centres with respect to the fire event realized in the Saraclar Street of Ulus historical city centre of Ankara on February 21, 2012. The fire affected directly 7 small firms operating in the area, leaving more than 100 people unemployed and causing a cost of damage for approximately 20 million Turkish Liras.

Departing from the disaster in Ulus city centre and following experience, the study focuses on the factors that affect urban vulnerability and the development of disaster mitigation strategies for historical business districts. The study combines the case of Saraclar Street fire and the literature on conservation of cultural properties, urban vulnerability, business continuity and disaster management in historical urban settings. The main argument of the study is that as well as the problems caused by the physical and spatial characteristics of historical city centres, the problems led by the business activities contribute to the urban risk production. Planning history of the area was investigated in order to explain the formation of spatial pattern, socio-economic structure, and business activity; and the factors that contribute to the production of urban vulnerability were analysed.

The affected street is a part of the historical business district that houses a traditional spatial layout and urban pattern as well as building stock. The poor quality and construction material of buildings, narrow streets and inadequate infrastructure increased the risks of the area. Additionally, it is shown that the area was planned as historical conservation zone but subjected to a deterioration process in time since the area used to serve to those from lower socio-economic status. Thus, the users of the area having a limited regeneration capability and inadequate institutional capacity of local governments and decision-makers contributed to the risks of the area. In addition to the decline of the historical centre, the businesses operating in the historical centre have constructed vulnerabilities through their business characteristics and attracting clients to the area. These factors contributed to the vulnerability of historical site that suffered from the damage in urban pattern, closure or relocation of businesses, increase in poverty of lower socio-economic groups, and loss of urban identity.

This investigation asserted that spatial structure produces vulnerability factors with respect to the problems related with building order, accessibility and infrastructure; the determinants of vulnerability of socio-economic structure relate with the user characteristics of historical city centre and limited regeneration capacity of economic and political order; and busi- 
ness operations increase vulnerability of historical centres due to their business characteristics and user attraction nature. Accordingly, disaster management policies addressing to historical city centres are proposed with respect to the conservation of historical sites and continuity of economic activity. Consequently, at first, mapping and documentation studies are required to prepare a base map for prioritisation and intervention, and to analyse and categorise the land-uses and buildings that contain hazardous and explosive contents. Secondly, the steps of mitigation planning are to be applied as determination of hazards; making urban development decisions; setting the codes for conservation and development; detecting intervention opportunities in case of emergencies; designing neighbouring relations; figuring out the social vulnerability factors; increasing awareness among local businesses, users, and local community; and supporting participation among actors such as local firms, NGOs, local governments, and academia to make the mitigation plans as collaborative products. Thirdly, prioritisation policies should be handled to determine the sites that necessitates the allocation of investments and resources urgently; to detect the historical buildings under the destruction risk by retrofitting; to limit the functioning of the businesses operating with hazardous materials; to retrofit public service buildings such as schools, hospitals, and museums; and to make the lifeline systems resistant against disasters. Fourthly, governments need to have adequate source and staff to intervene an emergency in the historical sites. And finally, following a disastrous event, recovery policies are initiated to keep the businesses in the historical area in order to sustain the economic vitality and urban identity; to direct the economic activities to proper locations along with the proposed central district development; and to create a coping capacity for further disasters by financial tools such as credits and loans.

\section{Kaynakça/References}

ABB - Ankara Büyükşehir Belediyesi (2005). 14.01.2005 tarih ve 210 sayılı Ankara Büyükşehir Belediyesi Belediye Meclisi Kararı, Ankara.

Alesch, D.J., Holly, J.N., Mittler, E. ve Nagy, R. (2001). Organizations at Risk: What Happens when Small Businesses and Not-for-Profits Encounter Natural Disasters. Small Organizations Natural Hazards Project, First Year Technical Report. University of Wisconsin-Green Bay. The Public Entity Risk Institute, Fairfax, VA. 
Amin, A. (1999). An institutionalist perspective on regional economic development. International Journal of Urban and Regional Research, 23, 265-78.

Balamir, M. (2007). Risk Yönetimi ve Yerel Yönetimler, Afet Risk Yönetimi, N. Erkan, vd. (Der.) Risk Azaltma ve Yerel Yönetimler, İstanbul: Marmara Üniversitesi ve Dünya Bankası.

Bolin, R. ve Stanford, L. (1998). The Northridge Earthquake: Vulnerability and Disaster. London: Routledge.

Cengizkan, A. (2006). 1957 Yücel-Uybadin İmar Planı ve Ankara şehir mimarisi. T. Şenyapılı (Der.) Cumhuriyet'in Ankara'sı içinde. Ankara: ODTÜ Yayıncılık.

Cengizkan, A. (2004). Ankara'nın ilk plani: 1924-25 Lörcher plani. Ankara: Arkadaş Yayınları.

Chang, S.E. ve Falit-Baramonte, A. (2002). Disaster Vulnerability of Businesses in the 2001 Nisqually Earthquake. Environmental Hazards, 4, 59-71.

Dahlhamer, J.M. ve Tierney, K.J., (1998). Rebounding from Disruptive Events: Business Recovery Following the Northridge Earthquake. Sociological Spectrum, 18, 121-141.

Dietch, E.A. ve Corey, M. (2011). Predicting long-term business recovery four years after Hurricane Katrina. Management Research Review, 34(3), 311-324.

Dinçer, İ. (2012). Kültür mirasinin korunmasında 'risklere hazırlık' kavramının gelişimi. Mimarlık, 364, 56-59.

Erkal, F., Kıral, Ö. ve Günay, B. (2005). Ulus tarihi kent merkezi koruma 1slah imar planı: 1986-2006 koruma planından yenileme planına. Planlama, 2005,4, 34-49.

Günal, İ. (2006). Ankara tarihi kent merkezinde planlama deneyimi. Planlama, 2006/4, 147-151.

Günay, B. (2005). 1/1000 ölçekli Ulus Tarihi kent merkezi koruma 1slah imar planı'na ilişkin açıklamalar. 21 Ağustos 2017 tarihinde http://v3.arkitera.com/v1/gundem/ulus/yazi3.htm adresinden erişildi.

Günay, B. (2006). Ankara çekirdek alanının oluşumu ve 1990 nazım planı hakkında bir değerlendirme. T. Şenyapılı (Der.) Cumhuriyet'in Ankara'sı içinde. Ankara: ODTÜ Yayıncilık.

Hewitt, K. (1983). Interpretations of Calamity: From the Viewooint of Human Ecology. London: Allen and Unwin.

Keskinok, Ç. (2010). Urban planning experience of Turkey in the 1930. METU Journal of the Faculty of Architecture, 27(2), 173-188.

Nigg, J. M. (1995). Business disruption due to earthquake-induced lifeline interruption. Preliminary Paper No. 220. Disaster Research Center, University of Delaware, Newark, DE.

NTV haber sitesi (2012). Ankara'nın tarihi çarşısında yangın. 21 Ağustos 2012 tarihinde http://www.ntv.com.tr/galeri/turkiye/ankaranin-tarihi-carsisindayangin,s5CqX9NnhkCVRqU5BRUaPQ adresinden erişildi.

Pine, J.C. (2009). Natural hazard analysis: Reducing the impact of disasters. Boca Raton: CRC Press. 
Powell, F. ve Harding, A. (2009). Business recovery and the rebuilding of commercial property. A. Harding (Der.) Shaken up: Proceedings of a workshop on recovery following the gisborne earthquake içinde (s. 38-59). Opus International Consultants Ltd., Lower Hutt.

Scott, A.J. (1988). New industrial spaces: Flexible Production, Organisation and Regional Development in North America and Western Europe. London: Pion.

Storper, M. (1997). The Regional world: Territorial development in a global economy. New York: Guilford Press.

Şahin Kadakal, P. ve Ubay Tönük, G. (2016). Tarihi çevreleri koruma sürecinde yaşanan fiziksel ve sosyo-kültürel değişim, Ankara-Ulus Tarihi Kent Merkezi İstiklal Mahallesi örneği. Uğurlar, A. vd. (Der.), Seksen Sonrası Mekan ve Planlama içinde. Ankara: Gazi Üniversitesi.

Tankut, G. (1993). Bir başkentin imarı. İstanbul: Anahtar Kitaplar.

Tierney, K.J. (1994). Business Vulnerability and Disruption: Data from the 1993 Midwest Floods, 41st North American Meetings of the Regional Science Association International, Niagara Falls, Ontario, Kasim 16-20, 1994.

Tierney, K.J. (1997). Business Impacts of the Northridge Earthquake. Journal of Contingencies and Crisis Management, 5(2), 87-97.

Tierney, K.J. ve Webb, G.R. (2001). Business vulnerability to earthquakes and other disasters. Preliminary Paper No. 320. Disaster Research Center, University of Delaware, Newark, DE.

Tunçer, M. (2013). Ankara tarihi kent merkezi yenileme alanı koruma planı, niteliği ve iptaline ilişkin gerekçeler. Ankara Araştırmaları Dergisi, 1(2), 10-34.

UNESCO web sitesi (2017). Reducing Disaster Risk at World Heritage Properties. 21 Ağustos 2017 tarihinde http://whc.unesco.org/en/disaster-risk-reduction/ adresinden erişildi.

UNISDR (2005). Hyogo Framework for Action 2005-2015: Building the Resilience of Nations and Communities to Disasters, World Conference on Disaster Reduction, Kobe, Hyogo, Japonya, 18-22 Ocak 2005.

UNISDR (2015). Sendai framework for disaster risk reduction 2015-2030, Third UN world conference on disaster risk reduction (WCDRR), Sendai, Japonya, 18 Mart 2015.

Wasileski, G., Rodrigues, H., ve Walter, D. (2011). Business closure and relocation: A comparative analysis of the Loma Prieta Earthquake and Hurricane Andrew. Disasters, 35(1): 102-129.

Webb, G.R., Tierney, K.J. ve Dahlhamer, J.M. (1999). Businesses and disasters: Empirical patterns of unanswered questions. Preliminary Paper No. 281. Disaster Research Center, University of Delaware, Newark, DE.

Webb, G.R., Tierney, K.J. ve Dahlhamer, J.M. (2002). Predicting long-term business recovery from disaster: a comparison of the Loma Prieta earthquake and Hurricane Andrew. Environmental Hazards, 4(2), 45-58.

Orhan, E. (2013). Politik yeniden yapılanmada kamu binalarının mekansal organizasyonu: Başkent Ankara örneği, 4. Kentsel ve Bölgesel Araştırmalar Sempozyumu 
Bildiriler Kitabı, s.283-299. KBAM (Kentsel ve Bölgesel Araştırmalar Ağı) ve Mersin Üniversitesi, Mersin, 28-30 Kasım 2013.

Orhan, E. (2015). The consequences of security cognition in post-disaster urban planning practices in the case of Turkey. Natural Hazards, 76(1), 685-703.

Orhan, E. (2016). Reading urban vulnerabilities through urban planning history: An earthquake prone city case from Turkey. METU JFA, 33(2), 139-159.

Zhang, Y., Lindell, M.K., ve Prater, C.S. (2009). Vulnerability of community businesses to environmental disasters. Disasters, 33(1), 38-57.

Dr. Ezgi Orhan Orta Doğu Teknik Üniversitesi Mimarlık Fakültesi Şehir ve Bölge Planlama Bölümü'nü 2007 yılında bitirdi. 2012 yılında ise ODTÜ Şehir ve Bölge Planlama Bölümü'nden doktora derecesini aldı. 2007-2012 yılları arasında ODTÜ Şehir ve Bölge Planlama Bölümü'nde araştırma görevlisi ve 2012-2015 yılları arasında Pamukkale Üniversitesi Şehir ve Bölge Planlama Bölümü'nde Yardımcı Doçent olarak çalıştı. 2015'ten beri Çankaya Üniversitesi Şehir ve Bölge Planlama Bölümü'nde Dr. Öğretim Üyesi olarak çalışmaktadır. Afet yönetimi ve planlaması üzerine tanınmış uluslararası dergilerde makaleleri yayınlanmıştır. Temel araştırma alanları afet yönetimi, işyeri coğrafyası ve planlama kuramlarıdır.

Dr. Ezgi Orhan graduated from the Department of City and Regional Planning at Middle East Technical University Faculty of Architecture in 2007. She received her PhD degree from the Department of City and Regional Planning at METU in 2012. She worked as a research assistant between 2007 and 2012 at METU Department of City and Regional Planning, and as assistant professor between 2012-2015 at Pamukkale University Department of City and Regional Planning. She has been currently teaching at Cankaya University Department of City and Regional Planning as assistant professor since 2015. She published several articles on disaster management and planning in international journals. Her main research interests are disaster management, business geography, and planning theory.

E-mail: ezgiorhan@cankaya.edu.tr

\section{Kaynakça Bilgisi / Citation Information}

Orhan, E. (2018). Tarihi kent merkezlerinin kırılganlığı ve afet yönetimi üzerine bir değerlendirme: Ankara Saraçlar Sokağı yangını örneği. IDEALKENT - Kent Araştırmaları Dergisi,

23, 189-215. 